(C) W. Selbitschka ${ }^{1}$, M. Keller ${ }^{2}$, U. Dresing ${ }^{1}$,

T. Dammann-Kalinowski ${ }^{1}$,

I. Krahn ${ }^{1}$, S. Schneiker ${ }^{\text {, }}$

D. Schäffer ${ }^{3}$, W. Lotz ${ }^{3}$,

R. Miethling-Graff ${ }^{4}$,

C. C. Tebbe ${ }^{4}$, A. Pühler ${ }^{1}$

${ }^{1}$ Lehrstuhl für Genetik, Fakultät für Biologie, Universität Bielefeld Germany;

${ }^{2}$ Bezirksregierung Düsseldorf, Germany;

${ }^{3}$ Institut für Mikrobiologie, Universität Erlangen-Nürnberg, Erlangen;

${ }^{4}$ Institut für Biodiversität, Johann Heinrich von Thünen-Institut, Bundesforschungsinstitut für Ländliche Räume, Braunschweig, Germany

A A field study was conducted with genetically modified Sinorhizobium meliloti strains L1 (RecA-) and L33 (RecA+), both tagged with the firefly luciferase $l u c$ gene as an identification marker. The strains' fate was studied over a time period of five years. Both strains were rapidly outcompeted for alfalfa nodulation by an indigenous population.

In summary, this study demonstrates the usefulness of tagging bacteria designed for environmental releases by the firefly luciferase gene and the high resilience of soil bacteria to allow the establishment of foreign bacterial populations.

Key words: alfalfa, Sinorhizobium meliloti, luc gene-tagging, nodulation competitiveness, indigenous populations, field releases of genetically modified bacteria.

\section{FATE AND ECOLOGICAL INTERACTIONS OF FIREFLY LUC GENE-TAGGED SINORHIZOBIUM MELILOTI 2011-BACTERIA IN SOIL INHABITED BY HIGH LEVELS OF INDIGENOUS ALFALFA NODULATING POPULATIONS}

A field study was conducted with genetically modified Sinorhizobium meliloti strains L1 $\left(\mathrm{RecA}^{-}\right)$and L33 $\left(\mathrm{Rec}^{+}\right)$, both tagged with the firefly luciferase luc gene as an identification marker. The strains were released as peat-based inocula at densities of approx. $10^{6} \mathrm{cfu}^{-1}$ soil in replicate and randomised field plots at a field site in Bavaria (Germany). The strains' fate was studied over a time period of five years. During the first six weeks after inoculation, the viable count of both $l u c$ tagged strains sharply dropped for more than two orders of magnitude. Thereafter, the titer of both strains more or less steadily declined within the next five years to approx. $10^{2} \mathrm{cfu} \mathrm{g}^{-1}$. No significant differences in the survival of strains L1 (RecA $\left.{ }^{-}\right)$ and L33 $\left(\mathrm{RecA}^{+}\right)$were noted at most sampling dates demonstrating that the recA gene function was dispensable under the prevalent environmental conditions. Both strains were rapidly outcompeted for alfalfa nodulation by an indigenous population which was well-established in the field site soil. RecA ${ }^{-}$strain L1 was slightly faster outcompeted than its isogenic $\mathrm{RecA}^{+}$counterpart L33. In order to mimic normal agricultural practice, one year after the field release the non-host plant rye was grown in a total of 21 of the 49 field plots. Cultivation of rye had neither a negative nor a positive effect on the survival of strains L1 and L33 in these plots, respectively. Both strains showed the same survival capabilities, comparable to that of the field plots were the host plant alfalfa was grown. The diversity of the indigenous population was characterized by employing the Enterobacterial Repetitive Intergenic Consensus (ERIC) PCR fingerprint method. Typing of more than 340 indigenous isolates recovered from alfalfa root nodules throughout the monitoring period of five years revealed the presence of five dominant strain types accounting for approximately $67 \%$ of the isolates of the indigenous alfalfa nodulating population. Nearly one third of the dominant isolates displayed the Rhizobium sp. Or191 fingerprint pattern. IS fingerprinting of representatives of the various strain types confirmed the ERIC fingerprint groups. Hence, the released strains L1 and L33 had been outcompeted by few dominant strains types. The field release experiment was terminated after five years by treatment of the field plots with the herbicide RoundUp ${ }^{\circledR}$. This procedure virtually eliminated both strains from the release site, as demonstrated by viable count determination. In summary, this study demonstrates the usefulness of tagging bacteria designed for environmental releases by the firefly luciferase gene and the high resilience of soil bacteria to allow the establishment of foreign bacterial populations.

The use of nitrogen fixing Sinorhizobium meliloti soil bacteria as seed inoculants to improve the yield of the crop plant alfalfa is an established agricultural practice for more than 100 years (Bashan 1998). With the advent of modern gene technology, the optimization of genetic traits involved in host plant nodulation or symbiotic nitrogen fixation has become feasible and field testing of such strains has already begun more than a decade ago (Amarger 2002, Hirsch 2004).

The use of genetically modified organisms (GMOs) in the field, however, requires their efficient detection accompanied by a thorough analysis of the potential ecological impact.

GMOs engineered for reduced survival in the environment, i.e. biologically contained GMOs is one strategy that has been developed to avoid its persistence after their activity is not desired anymore. Therefore, RecA-deficient strains were proposed as genetically debilitated model strains for deliberate release exeriments with Sinorhizobium meliloti (Selbitschka et al., 1991). Towards this end, an isogenic pair of $S$. meliloti strains, strains L1 (RecA ${ }^{-}$) and L33 (RecA+), respectively, differing in their ability to perform recA-mediated homologous recom- 
bination was constructed. As the identification marker the North American firefly (Photinus pyralis) luciferase (luc) gene conferring bioluminescence was used which proved to be highly sensitive and unequivocal in the detection of tagged strains in non-sterile soil samples (Selbitschka et al., 1992).

To assess the relevance of an intact $r e c A$ gene function for the strains' survival in soil, laboratory and greenhouse-based microcosm experiments (Hagen et al., 1997; Niemann et al., 1997a; Schwieger et al., 1997), experiments in field lysimeters (Schwieger et al. 2000b) and finally, a field release experiment was performed (Selbitschka et al. 2006). In particular, the field study which was conducted in field plots of the Federal Research Institute for Agriculture (FAL; now Johann Heinrich von Thünen-Institute, Federal Research Institute for Rural Areas, Forestry and Fisheries) in Northern Germany in the year 1995 had raised several questions which were addressed in the present field study. These were (i) the extent of the accidental dispersal of inoculant strains during the release procedure when the strains were released as peat-based inoculants, (ii) the comparative survival of the isogenic RecA ${ }^{+} / \mathrm{RecA}^{-}$strains under the prevalent environmental conditions, (iii) the influence of the presence of an indigenous alfalfa nodulating population on the establishment and the persistence of both strains in soil as well as (iv) the influence of the growth of the non-host plant rye on the population dynamics of the release strains as an example for crop rotation in normal agricultural practice .

\section{RESULTS}

\section{Inoculation of field plots and analysis of the aerial spread of the luc tagged release strains}

The bacterial strains were released onto the field plots on August $28^{\text {th }}, 1997$. The release procedure took about 7 hours corresponding to approx. 9 min. inoculation time for each of the 49 field plots. During the bacterial release a moderate southwesterly wind at a maximum velocity of $2.5 \mathrm{~m} \mathrm{~s}^{-1}$ was recorded. Aerial spread of the strains was monitored employing sedimentation plates (yellow circles in Fig. 1). The minimal and maximal number of bioluminescent colonies varied between zero and 10 for the release of strain $\mathrm{L} 1$ and between zero and 21 for the release of strain L33 (data not shown). The number of bioluminescent colonies grown on the sedimentation plates which were opened over the entire release procedure varied between zero and 19 colonies. Figure 2 shows the aerial spread of the bioluminescent strains of the latter type of sedimentation plates. None of the 50 sedimentation plates placed along the fence and in the perennial alfalfa stand (brown circles in Fig. 1) contained bioluminescent colonies.

In order to test whether the recombinant strains had been accidentally dispersed to the 2011 or non-inoculated field plots, soil samples were analysed from all of these plots.

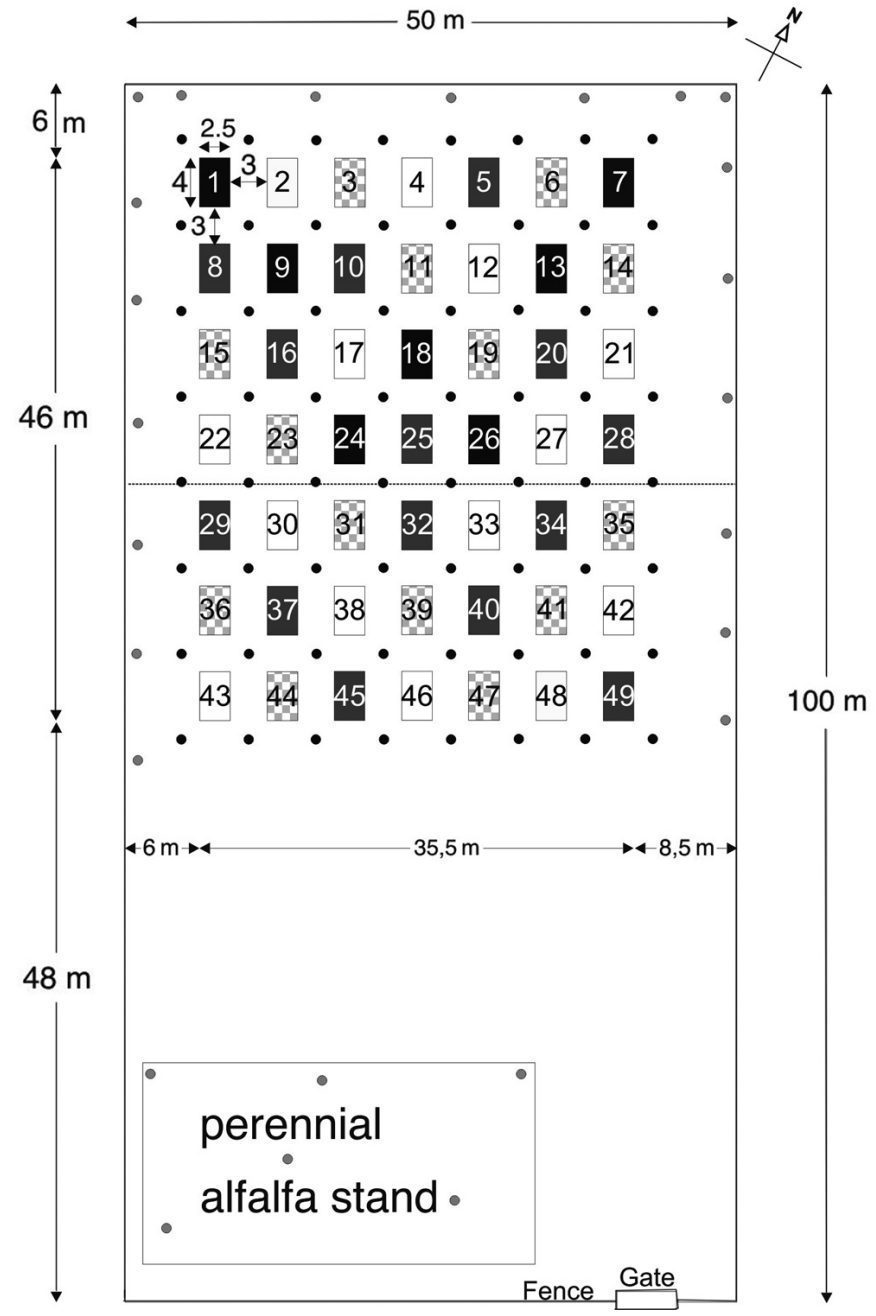

Fig. 1. Schematic representation of the release site in Strassmoos, Bavaria, Southern Germany.

The field site which is 5.000 square meters in size $(50 \mathrm{~m} \times 100 \mathrm{~m})$ is bordered by a fence. Each of a total of 49 field plots was 10 square meters in size $(2.5 \mathrm{~m} \times 4 \mathrm{~m})$. The field plots were separated from each other by a $3 \mathrm{~m}$ distance. The randomly arranged field plots were inoculated with bioluminescent strains L1 (blue), L33 (red) or wild type strain 2011 (green), respectively, or remained uninoculated (grey). The dashed line which separates the lower three rows from the upper four rows of the field plots indicates that a different regime was used for those plots. After alfalfa plants were cut in September 1998, rye seeds were seeded in field plots 29 to 49 . The yellow circles indicate a total of 192 sedimentation plates with each circle representing three plates. The plates were opened either during the entire release procedure (type I plates) or only during the release of strain L1(type II plates) or L33 (type III plates), respectively. The brown circles indicate sedimentation plates positioned near the fence and within a perennial alfalfa stand where alfalfa plants were grown since 1993. The entrance to the field site is via a gate. 


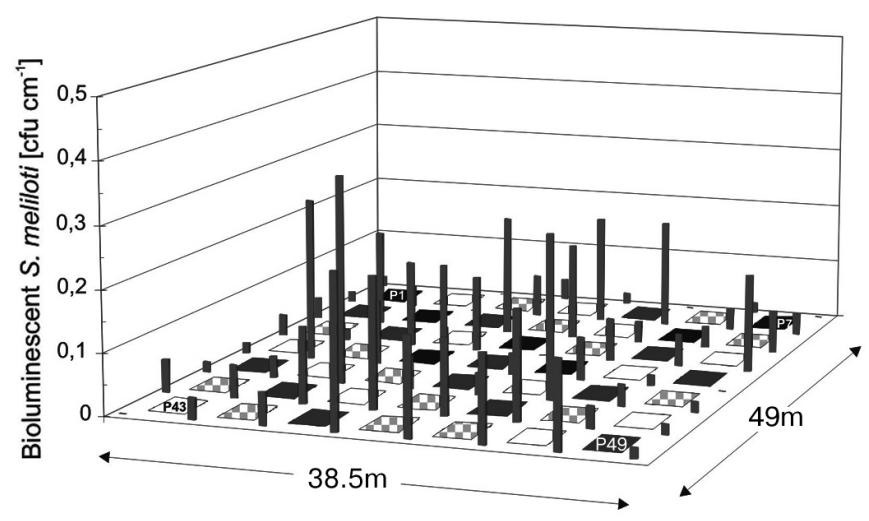

Fig. 2. Aerial spread of $S$. meliloti strains L1 ( $\left.\operatorname{RecA}^{-}\right)$and L33 $\left(\operatorname{RecA}^{+}\right)$during field plot inoculation.

The calculated number of bioluminescent $S$. meliloti colonies per $\mathrm{cm}^{2}$ grown on type I sedimentation plates which were opened during the entire release procedure (see black circles in Fig. 1) is shown by bars. Field plot number 1 (P1) is shown in the upper left corner while field plot number 49 (P49) is shown in the lower right corner of the field site. Please note that the field plots are not drawn to scale.

Moreover, the aerial spread was also assessed in soil samples of the alfalfa stand. With the exception of plot number 10 (non-inoculated) where a total of $33 \mathrm{cfu}^{-1}$ soil was recorded, in none of the 2011 inoculated or the non-inoculated plots GMOs were identified. No bioluminescent colonies were detected in soil samples taken from the alfalfa stand.

\section{Population dynamics of S. meliloti strains L1 and L33 in field plots containing alfalfa plants}

Soil samples taken immediately after field plot inoculation revealed titers averaging $9.3 \times 10^{5} \mathrm{cfu} \mathrm{g}^{-1}$ soil for RecA ${ }^{-}$strain L1 and $1.3 \times 10^{6} \mathrm{cfu} \mathrm{g}^{-1}$ soil for RecA ${ }^{+}$ strain L33 in their respective field plots. Within a period of 6 weeks the titers of both strains dropped for more than two orders of magnitude to approx. $10^{4} \mathrm{cfu} \mathrm{g}^{-1}$ (Fig. 3A). After a further decline in April 1998, the titer of both strains essentially remained stable at around $7 \times$ $10^{3}$ cfu g $^{-1}$ soil until April 1999. Thereafter, with the exception of the sampling date July 1999, which showed an anomalous increase of strain's L33 viable count, the titer of both strains more or less steadily declined until March 2002 to approx. $10^{2} \mathrm{cfu}^{-1}$. At most sampling dates no significant differences in the survival of the RecA-deficient strain L1 was detected compared to the $\mathrm{RecA}^{+}$strain L33.

Field plot number 10, which was a non-inoculated control plot of the release experiment had been accidentally contaminated with bioluminescent strain L33 during the release procedure. Since during the next two sampling dates no bioluminescent colonies could be detected, the field plot was omitted from further monitoring.
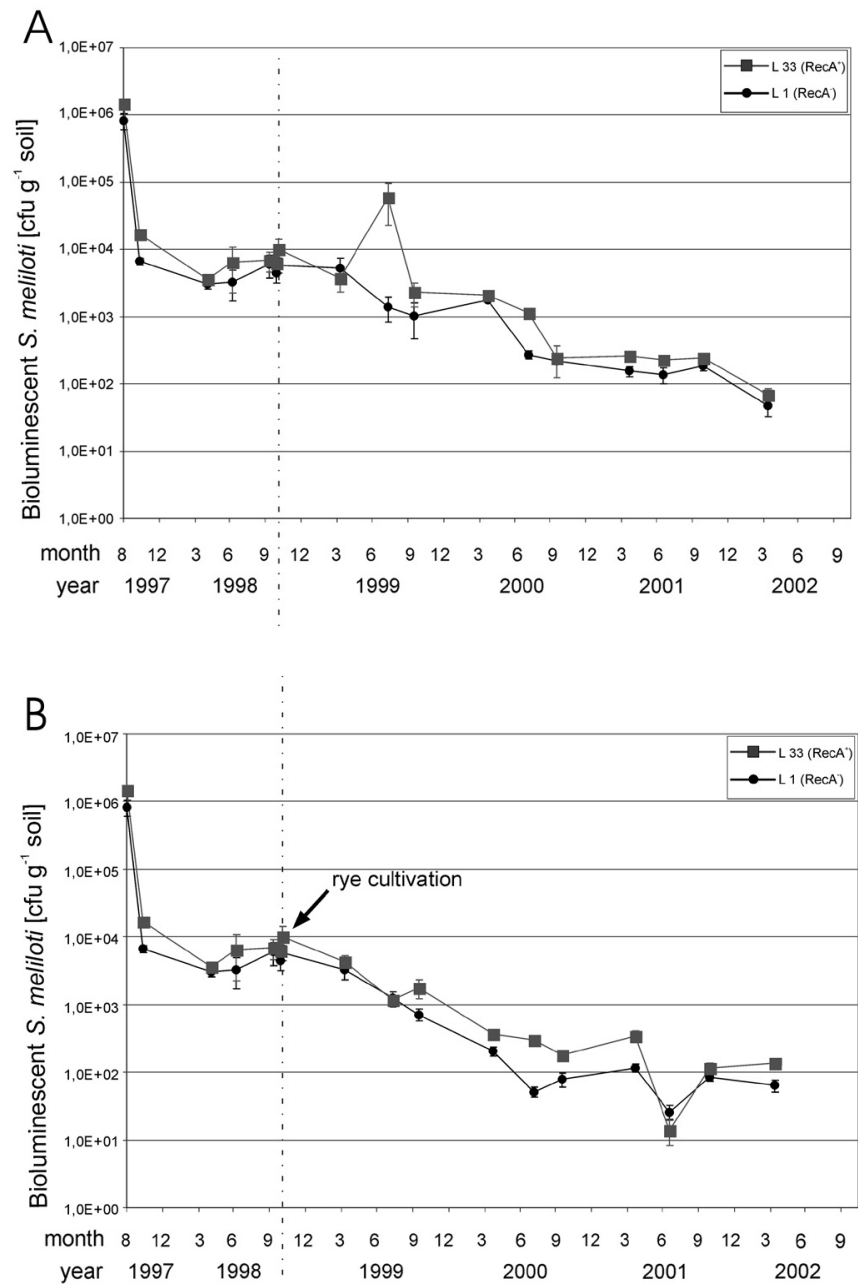

Fig. 3.Survival of $S$. meliloti strains L1 (RecA-; circles) and L33 (RecA ${ }^{+}$; squares) in field plots with co-cultivated alfalfa $(A)$ and rye plants $(B)$.

(A) Each of the values shown for the first seven sampling dates (August 1997 to September 1998) represents the average titer calculated from the combined data of fourteen field plots \pm standard error. The values from September 1998 until March 2002 represent the average titer calculated from seven field plots \pm standard error. In May 2002 the field experiment was terminated by applying the herbicide RoundUp.

(B) Survival of $S$. meliloti strains L1 (RecA-; circles) and L33 (RecA+; squares) in field plots with co-cultivated alfalfa (August 1997 to September 1998) and rye plants (September 1998 to October 2002). Each of the first seven values represents the average titer calculated from the combined data of fourteen field plots \pm standard error. On September $28^{\text {th }}, 1998$, rye seeds were sown in field plots 29 to 49 (solid arrow) and the survival of strains L1 (black line) and L33 (grey line) was determined. The remaining values from September 1998 until March 2002 represent the average titer calculated from seven field plots \pm standard error. In May 2002 the field experiment was terminated by applying the herbicide RoundUp to the field plots. 


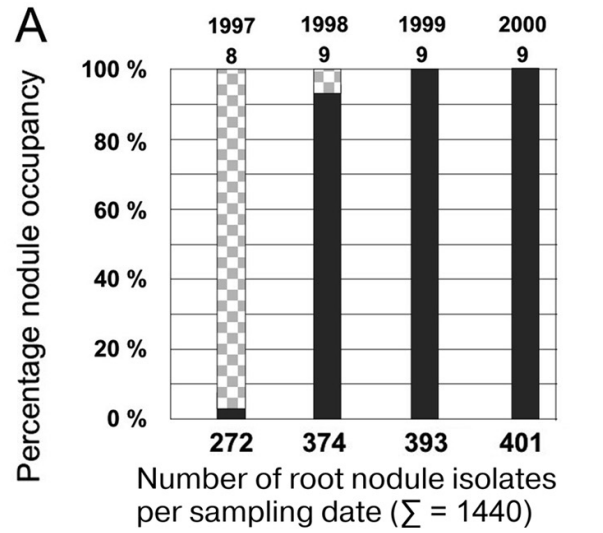

L1 $\left(\operatorname{RecA}^{-}\right) \square$ L33 $_{\left(\operatorname{Rec} A^{+}\right)}$
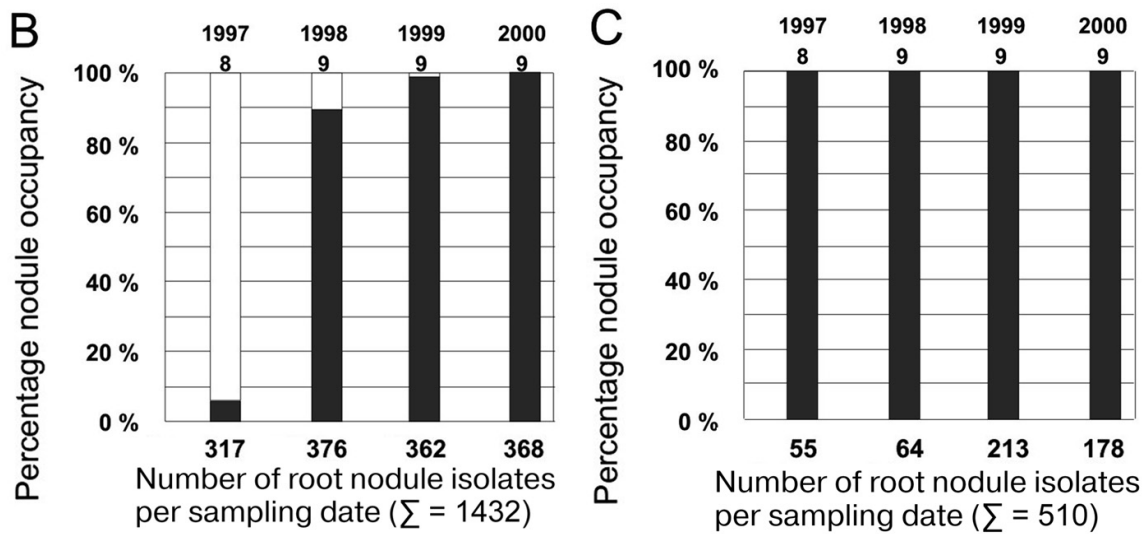

Number of root nodule isolates per sampling date $(\Sigma=510)$

Fig. 4. Nodule occupancy of S. meliloti strains L1, L33 and of strains of the indigenous alfalfa nodulating population.

Root nodules were obtained from alfalfa plants grown in soil samples taken from L1 (A), L33 (B) and non-inoculated (C) field plots. The nodule occupancy is given in percent. The number of root nodule isolates which were analyzed at each sampling date as well as the total number of isolates in the corresponding year is given below the bar. The month and year of sampling is indicated above the bars. The percentage of nodules occupied by strains L1 (checker), L33 (white) and by strains of the indigenous population (grey) is shown.

\section{Population dynamics of S. meliloti strainsL1 and L33 in field plots containing rye plants}

In order mimic normal agricultural practice, the impact of the cultivation of the non-host plant rye on the population dynamics of both strains was evaluated. For this purpose, field plots number 29 to 49 were seeded with rye seeds on September 28th, 1998 (arrow in Fig. 3B).

Thereafter, the viable count of strains L1 and L33, respectively, was monitored until March 2002.

The titer of both strains showed a steady decline from approx. $10^{-4}$ to $10^{-2} \mathrm{cfu} \mathrm{g}^{-1}$ soil, with no significant differences in the survival capabilities of strains L1 and L33, respectively during most of the sampling dates (Fig. 3B). A significant reduced survival of RecA- ${ }^{-}$strain $\mathrm{L} 1$ compared to its counterpart L33 was noted during the sampling dates June 2000 and January $2001(\mathrm{P} \geq 0.05)$.

\section{Competition for alfalfa nodulation between the indigenous population and the luc-tagged release strains}

In order to assess the competition for alfalfa nodulation between the release strains and the indigenous population, soil samples taken from the field plots were filled in microcosms.

Thereafter, alfalfa seedling were added and the microcosms were incubated in a growth chamber. Root nodule isolates were recovered and characterized as describe in the materials and methods section.

In soil samples taken immediately after the bacterial release and used for nodulation assays in the glasshouse, approx. $96 \%$ and $95 \%$ of the root nodules were occupied by strains L1 and L33, respectively (Fig. 4). Soil samples taken from the $\mathrm{L} 1$ inoculated field plots in the following year 1998 showed a decrease of the proportion of L1 occupied nodules to $7 \%$. No L1 induced root nodules were observed in the years 1999 and 2000, respectively. In soil samples taken from the L33 inoculated plots a similar decrease was observed albeit at a slightly lesser extent. The proportion of L33 occupied root nodules fell from $11 \%$ in the year 1998 to $16 \%$ in the year 1999. In 2000, strain L33 could not be recovered from root nodules anymore (Fig. 4).

\section{Genetic stability of the luc marker gene in the release strains}

In order to estimate the genetic stability of the marker gene in the release strains, root nodule isolates obtained in the above described experiments were characterized phenotypically for streptomycin resistance and bioluminescence, and at the molecular level by employing $l u c$ and ERIC PCR.

A total of 440 streptomycin-resistant isolates recovered from root nodules of alfalfa plants grown in soil samples taken from the L1 inoculated field plots were tested for bioluminescence in a luminometer. All isolates tested displayed a bioluminescent phenotype.

The presence of the luc gene sequence was evaluated in 368 isolates using luc-specific PCR. All isolates tested yielded a specific DNA-fragment of 415 bp for strain L1. The identity of a further subfraction comprising 109 isolates was established employing ERIC PCR. All isolates tested displayed the L1-specific ERIC fingerprint pattern, i. e. were GMO's (data not shown).

A total of 502 streptomycin-resistant isolates reisolated from root nodules of alfalfa plants grown in soil samples taken from the L33 inoculated plots were tested for their bioluminescent phenotype. All isolates tested displayed a bioluminescent phenotype. The presence of the luc gene sequence was assessed for 427 isolates. All isolates test- 
ed yielded the L33-specific DNA which is 1011 bp in size. Again, the identity of a subfraction of 86 isolates was tested employing the ERIC PCR method. In all cases tested, the isolates displayed the L33-specific ERIC fingerprint pattern, i.e. were GMOs (data not shown).

A total of 296 root nodules isolated from alfalfa plants grown in the non-inoculated plots were also analysed for their bioluminescent phenotype. None of the root nodule isolates displayed bioluminescence. The ERIC fingerprint was established from 129 of those isolates.

All isolates tested displayed an ERIC fingerprint pattern clearly different from that of strains L1 and L33, respectively, i. e. belonged to the indigenous population (see below).

\section{Characterization of the diversity of the alfalfa nodulating indigenous population by ERIC PCR typing and IS fingerprinting}

In the course of establishing the identity of root nodule isolates, 342 isolates of the indigenous alfalfa nodulating population had been typed employing the ERIC PCR fingerprint technique. According to their ERIC fingerprint pattern, the majority of those isolates, i.e. 228 strains were grouped into five dominant fingerprint groups. The remaining 114 isolates fell into 23 fingerprint groups ( 1 to 8 isolates per group). Fingerprint group I which comprised a total of 74 strains was the most dominant group. Isolates of this fingerprint group displayed the Rhizobium sp. Or191 (Eardly et al. 1992) specific fingerprint pattern (data not shown).

Fingerprint groups II to VI comprised 44, 26, 46, and 38 isolates, respectively. In order to confirm the grouping of isolates according to their ERIC fingerprint pattern, representatives of the ERIC fingerprint groups II to V, namely strains SM11, SM 15, SM19 and SM31, respectively, were subject to Southern hybridizations employing the S. meliloti IS element ISRm2011-2 as a probe. Two isolates representative for two dominant fingerprint groups of the Braunschweig release site designated BS9 and BS13, respectively, were included as controls.

The hybridizations confirmed the genetic diversity of all isolates, i.e. all isolates displayed a different IS fingerprint pattern. However, the IS fingerprint pattern of all isolates to some extent displayed similarity indicating genetic relatedness among the isolates (Fig. 5).

\section{Analysis of the ecological impact of the GMO release}

In order to identify unintended negative effects of the bioluminescent $S$. meliloti strains and their parental strain on soil in general, soil chemical parameters were analyzed four times, immediately after the bacterial release, in in August and October 1997 and annually from 1998 to 2001 in September. Total carbon was determined with $9.56 \mathrm{~g} \mathrm{C} \mathrm{kg}^{-1}$ dry soil in average and ammonia with $1.53 \mathrm{mg} \mathrm{N} \mathrm{kg}{ }^{-1}$ dry soil with no significant difference between the variants, the season or the year of analysis (data not shown). Nitrate decreased on all field plots within the first year after the release

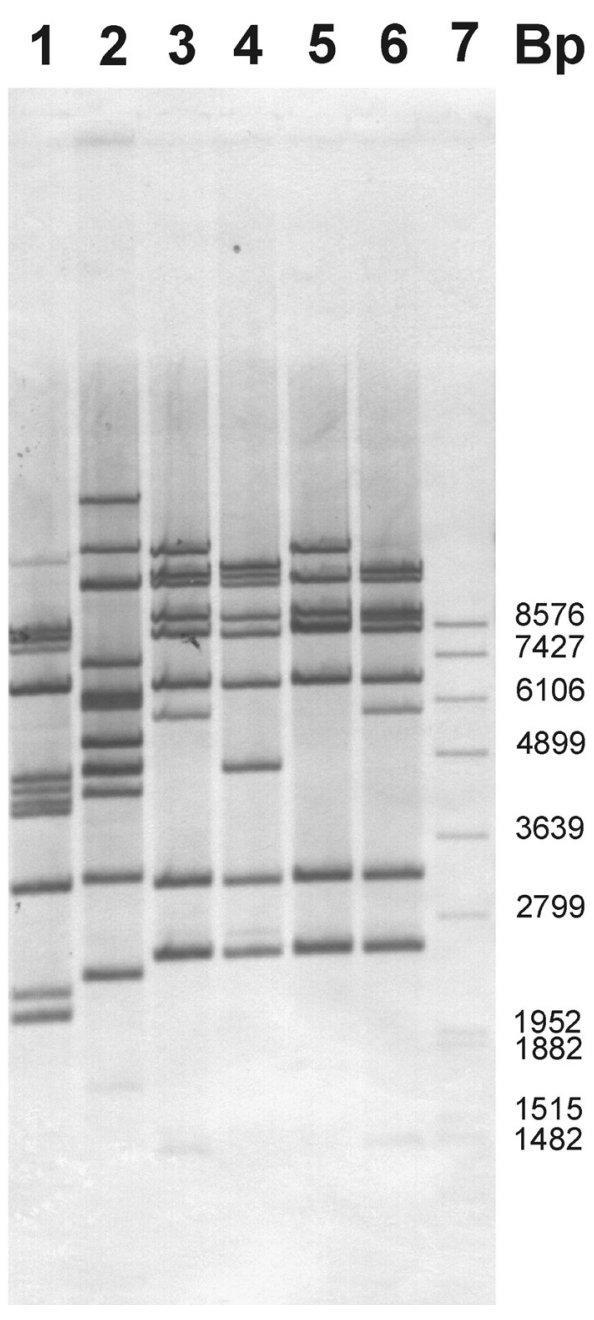

Fig. 5. Southern blot hybridization of representative $S$. meliloti strains of indigenous alfalfa nodulating populations from the Strassmoos (lanes 1-4; strains SM11, SM 31, SM15, SM19) and the Braunschweig (lanes 5, 6; strains BS13, BS9) release sites, respectively, with labeled ISRm2011-2 DNA.

Total DNA was restricted with EcoRI and separated by agarose gel electrophoresis. The fragment sizes for the digoxigenin-labeled marker VII (lane 7) are indicated on the right.

from $13.68 \mathrm{mg} \mathrm{N} \mathrm{kg}^{-1}$ dry soil to $4.35 \mathrm{mg} \mathrm{N} \mathrm{kg}^{-1}$ dry soil in average. This level remained for the following years in the same magnitude but with some significant deviations along the time course. However, the fluctuations were in the expected range of $\mathrm{N}$-contents in agricultural soils (data not shown) and there was no effect of the specific inoculations.

The annual analysis of the microbial biomass and the determination of culturable heterotrophic soil bacteria, respectively, revealed no impact of any of the inoculations. While the numbers of the culturable heterotrophic bacteria remained constant along the experiment, the microbial biomass decreased from $468 \mathrm{mg} \mathrm{C} \mathrm{kg}^{-1}$ soil within the first two years to $109 \mathrm{mg} \mathrm{C} \mathrm{kg}^{-1}$ in average. 


\section{Elimination of the released luc tagged strains from the field plots by RoundUp treatment}

In order to terminate the release experiment i. e. to recycle the GMO containing field plots for normal agricultural use, the field plots were treated with the herbicide RoundUp In 2002, Roundup was applied twice to all field plots in May and June. The titer of strain L1 fell below the detection limit in all field plots. In soil samples taken during fall 2002 with the exception of field plot 23 (L33 inoculated) which contained $15 \mathrm{cfu} \mathrm{g}^{-1}$ soil, in none of the plots bioluminescent cells were detected (data not shown). Consequently, the field site was finally approved for further agricultural use.

\section{DISCUSSION}

The fate of bioluminescent strains L1 $\left(\mathrm{RecA}^{-}\right)$and L33 $\left(\mathrm{RecA}^{+}\right)$released in field plots located in Bavaria, Southern Germany was assessed in a field study. The release experiment should specifically answer questions on (i) the extent of the aerial spread of GMOs during the release procedure, (ii) the strains' survival under the specific conditions prevalent at the Strassmoos field site, (iii) the influence of the presence of an established alfalfa nodulating population on the strains' persistence and, finally (iv) the influence of the growth of the non-host plant rye on the population dynamics of the release strains as an example of crop rotation as a normal agricultural practice. These issues were raised in the course of a previous long-term field study at the Federal Research Center (FAL) Braunschweig (Northern Germany) in the year 1995 (Selbitschka et al. 2006).

In the present study, the inoculant strains were applied to the field plots bound on peat as carrier material. The release of both strains resulted in a low accidental dispersal as inferred from the results obtained with the sedimentation plates. In average only 5 bioluminescent colonies were counted per plate. In contrast, in the FAL field study, the release strains had been applied as liquid cultures onto the surface soil of field plots. The accidental dispersal of the strains which occurred at a rate of approx. 50 to 700 cells per agar plate was attributed to aerial spread by wind (Selbitschka et al. 2006). Thus, compared to the FAL field study the unintended dispersal was reduced by one to two orders of magnitude. These results clearly demonstrate that with regard to the accidental dispersal, the field application of GMOs bound on solid carrier material is superior to the spraying technique.

During the first six weeks after inoculation, the viable count of both strains showed a sharp decrease. This initial decrease in viable count is a frequent observation if bacteria are introduced in soil (van Veen, 1997) and was also observed during the FAL field experiment (Selbitschka et al. 2006). However, the drop in the viable count was much faster at the Strassmoos field site ( 6 vs. 14 weeks). This discrepancy may be explained by a seasonal effects.
The strains were released at the Strassmoos field site at the end of August, i.e. at the end of the growing season whereas in the FAL study the release was performed in April, i. e. at the start of the growing season. Alternatively, this discrepancy may be explained by competition effects.

The field plots of the Strassmoos site harbored a well-established alfalfa nodulating population whereas in the FAL study no indigenous population was present at the time of the strains' release in the field plots.

During the subsequent years no pronounced seasonal increase and decrease in viable count of both strains was noted. This result contrasts the results of the FAL study where a seasonal increase and decrease in viable counts of both strains was detected which had been attributed to the well-known rhizosphere effect exerted by the host plant alfalfa (Selbitschka et al. 2006). However, our previous microcosm experiments using soil samples from the same field site had shown that this growth stimulating rhizosphere effect was not observed when strains L1 and L33 had been inoculated in soil samples which contained an indigenous alfalfa nodulating population (Hagen et al. 1997).

The assumption that competition with the indigenous alfalfa nodulating population is a major factor influencing the population dynamics of the release strains is further corroborated by the observation, that although small numbers of strain L33 were accidentally dispersed to non-inoculated plots they could not establish there. This is in contrast to the observation of the FAL field study, where strain L33 which was accidentally dispersed to non-inoculated field plots could establish to a similar extent as in the L33 inoculated field plots (Selbitschka et al. 2006).

Virtually all root nodules of alfalfa plants grown in soil samples taken from the field plots immediately after inoculation with strains L1 and L33, respectively, were occupied by the released strains. However, already one year later, the nodule occupancy of strain L1 had decreased to approx. 7 $\%$ and that of strain L33 to approx. $12 \%$. Hence, approx. $93 \%$ of root nodules were occupied by strains of the indigenous alfalfa nodulating population in the $\mathrm{L} 1$ inoculated field plots and $88 \%$ in the L33 inoculated field plots, respectively. It is a frequent observation that inoculant strains are readily outcompeted for host plant nodulation if a better adapted indigenous population is present in soil (e. g. Thies et al. 1991).

The RecA-deficient strain L1 was less competitive for alfalfa nodulation than its counterpart L33, a result which has been consistently found in microcosm experimentes (Herrera-Cervera et al. 1997, Niemann et al. 1997a) but also in the FAL field study (Selbitschka et al. 2006). During the subsequent years, the proportion of indigenous strains in alfalfa root nodules increased to $100 \%$. Thus, both strains were readily outcompeted for alfalfa nodulation by the indigenous population.

In the context of the deliberate release of GMOs, the genetic stability of release strains is of relevance. This ap- 
plies for instance to the lateral transfer of the transgenic trait to members of the indigenous population. Moreover, the stability of the marker gene expression in the GMOs is of importance, too. During the field study none of the bioluminsecent root nodule isolates displayed an ERIC fingerprint different from the L1/L33 specific ERIC fingerprint pattern.

Thus, no transfer of the luc gene to indigenous alfalfa nodulating bacteria was observed. In turn, all non-bioluminescent root nodule isolates typed with the ERIC PCR technique displayed an ERIC fingerprint pattern which differed from the L1/L33 fingerprint pattern. Hence, no inactivation of the bioluminescence phenotype had occurred. In conclusion, neither a high frequency transfer of the bioluminescence phenotype nor the inactivation of the luc gene marker at a high frequency was observed. These observations are in accordance with the results obtained during the FAL field study and emphasize the suitability of the luc marker for ecological studies (Selbitschka et al. 2006).

Since alfalfa pants had been repeatedly grown for several years at the Strassmoos field site, an indigenous alfalfa nodulating population was well established at the time of the release of strains L1 and L33, respectively. The molecular characterization of the diversity of the indigenous population by employing the ERIC fingerprint technique revealed a total of five dominant strain types. Interestingly, the most prominent group which comprised nearly one third of the dominant isolates showed the Rhizobium sp. Or191-specific fingerprint pattern. This result indidated that a large proportion of the alfalfa nodulating indigenous population at the Strassmoos release site did not belong to the genus Sinorhizobium. None of the isolates showed the Sinorhizobium medicae-specific ERIC fingerprint pattern. $S$. medicae is another species of Sinorhizobium, known for its ability to effectively nodulate alfalfa.

Is fingerprinting of representatives of the four $S$. meliloti ERIC fingerprint groups confirmed the grouping of isolates according to their ERIC fingerprint pattern. Interestingly, strains BS 9 and BS13 recovered from the Braunschweig release site were closely related to strains SM15 and SM19. This observation indicates that the same dominant strain types were present at two different locations some $600 \mathrm{~km}$ apart. Thus, closely related dominant strain types which were apparently more competititve for alfalfa nodulation had outcompeted the GMOs at the Strassmoss and the Braunschweig release site.

Previously, the molecular basis for the nodulation competitiveness of strains belonging to dominant ERIC fingerprint groups described in this paper was addressed. Strain $S$. meliloti SM11 which belongs to the dominant ERIC fingerprint group I of the Strassmoos release site was shown to harbor two cryptic plasmids which were designated pSmeSM11a and pSmeSM11b, repectively. Both plasmids were subject to sequence analysis (Stiens et al, 2006, 2007). Analysis of the $144 \mathrm{~kb}$ plasmid pSmeSM11 a revealed sev- eral genetic functions related to alfalfa nodulation such as additional copies of nodP and nodQ which are involved in Nod factor sulfation. Moreover, the acdS gene encoding ACC deaminase was identified, which was proposed to be involved in reducing the phytohormone ethylene and thereby influencing nodulation events (Stiens et al. 2006). A recent study which addressed the distribution of pSmeSM1 1a specific sequences in strains belonging to dominant ERIC fingerprint groups of the FAL study (Selbitschka et al. 2006) and of this work demonstrated the widespread occurrence of such plasmid types (Kuhn et al. 2008). In conclusion, these studies provided some clue about the possible cause why the indigenous population had readily outcompeted strains L1 and L33 for alfalfa nodulation at both release sites.

In order to mimic normal agricultural practice, the nonhost plant rye was grown in a total of 21 field plots one year after the start of the release experiment and the survival of the release strains was monitored (see Figs. 1 and 3). No differences in the survival capabilities of the release strains grown either in the alfalfa or rye plant containing field plots, respectively was observed. This result is in accordance with a previous greenhouse study reported by Miethling et al. (2000). In this work the survival of strain L33 was assessed in microcosms containing soil from the Strassmoos site and co-cultivated alfalfa or rye plants, respectively. No statistically significant differences were observed in the strain's survival capabilites in bulk soil irrespective whether alfalfa or rye plants were co-cultivated with the strain (Miethling et al. 2000).

Resilience of soil may be the ultimate method to remove recombinant bacteria in the environment. In a previous study by Miethling and Tebbe (2004), several resilience methods were tested in microcosm studies in the greenhouse to eliminate bioluminescent $S$. meliloti strain L33 from soil. The results shown in this study clearly demonstrate that this method can be considered an effective means for eliminating $S$. meliloti GMO from soil.

\section{MATERIALS AND METHODS}

\section{Bacterial strains and growth conditions}

The $S$. meliloti strains used in this study were strain $2011\left(\mathrm{Sm}^{\mathrm{R}}\right.$, Casse et al., 1979) which is a variant of strain 1021 whose genome sequence has been established (Galibert et al., 2001), strain L1 ( $\mathrm{Sm}^{\mathrm{R}}$, $\mathrm{Luc}^{+}, \mathrm{RecA}^{-}$; Selbitschka et al., 1992) and strain L33 ( $\mathrm{Sm}^{\mathrm{R}}$, Luc ${ }^{+}, \mathrm{RecA}^{+}$; Selbitschka et al., 1995a), respectively. Moreover, indigenous isolates of the alfalfa nodulating population of the Strassmoos release site (strains SM11, SM15, SM19, SM31) as well as the Braunschweig release site (strains BS9, BS13) were included in this work. The bacteria were grown at $30^{\circ} \mathrm{C}$ on TY agar medium (Beringer 1974). NPM A Medium (Bromfield et al., 1994) supplemented with $500 \mathrm{mg} \mathrm{l}^{-1}$ streptomycin $(\mathrm{Sm})$ and $100 \mathrm{mg}^{-1}$ cycloheximide was used to grow bacteria extracted from soil samples. 


\section{Soil characteristics of the release site (Strassmoos)}

The soil type of the release site was brown earth, sandy loam soil with a $\mathrm{pH}$ value of 5.9 .

The nitrate content was $61.91 \mathrm{mg} \mathrm{N} \mathrm{kg}^{-1}$ soil, the ammonia content was $2.36 \mathrm{mg} \mathrm{N} \mathrm{kg}^{-1}$ soil. Total organic carbon was $9.62 \mathrm{~g} \mathrm{C} \mathrm{kg}^{-1}$ soil. Alfalfa had been grown frequently at the release site during the past 5 years before the release. The number of alfalfa nodulating rhizobia was $10^{5}$ cells $\mathrm{g}^{-1}$ soil as determined employing the most probable number (MPN) test (Somasegaran and Hoben, 1994).

\section{Experimental design and release of the bacterial strains}

The release site comprised a total of 5.000 square meters. The entire area was bordered by a fence. The release site consisted of 49 field plots, with each plot 10 square meters in size $(2.5 \mathrm{~m} \times 4 \mathrm{~m})$. Fourteen plots were used for inoculation with strain L1, 14 plots with strain L33, 7 plots with wild type strain 2011 and 14 plots remained un-inoculated. Each plot was separated from adjacent plots by a $3 \mathrm{~m}$ distance. The area also contained a long standing alfalfa site (Fig. 1).

To ensure that a high number of indigenous alfalfa nodulating bacteria was present in the field plots, alfalfa plants were grown in the prospective field plots one year before the bacterial release. Four weeks before the release, grass ( $P o a$ spec.) was seeded at the field site with the exception of the field plots. One day before the strains were released, approximately 10.000 alfalfa seeds (Medicago sativa cv. Europe) were sown automatically in each of the 49 field plots.

In parallel, the number of indigenous alfalfa nodulating bacteria was determined using the MPN test. These analyses revealed that an indigenous population was present at a titer of approx. $1 \times 10^{5} \mathrm{cfu} \mathrm{g}^{-1}$ soil.

The inoculant S. meliloti strains 2011 , L1, and L33 were prepared as HiStick ${ }^{\circledR}$ formulations (sterile peat with inbuilt sticker) by Microbio Ltd. (Hemel, Hempstead, UK). The viable counts of the strains were determined per gram of peat with $3.1 \times 10^{9}$ cfu for strain L1, $4.0 \times 10^{9}$ cfu for strain L33 and $6.0 \times 10^{9} \mathrm{cfu}$ for wild type strain 2011 , respectively. For the inoculation of each plot, $25 \mathrm{~kg}$ quartz sand was mixed with the peat-based inoculants (L1: $1.048 \mathrm{~g}$; L33: $812 \mathrm{~g}$; 2011: $541 \mathrm{~g}$ ) and applied to the plots by hand. Thereafter, each plot was watered in order to avoid desiccation of the inoculants and to reduce aerial spread.

In order to assess the aerial spread of the release strains, sedimentation plates were put around the field plots. A total of 192 agar plates ( 3 sets of 64 plates each) were placed between the field plots on $15 \mathrm{~cm}$ high blocks as indicated in Fig. 1 (yellow circles). One set of the agar plates (64 plates numbered from 1 to 64 ) remained open during the entire release procedure. The other two sets (128 plates) were opened successively during the release of strain L1 (numbers 65 to 128) or strain L33 (numbers 129 to 192), respectively. Another set of $2 \times 25$ sedimentation plates was placed along the fence as well as in a perennial alfalfa stand (brown circles in Fig. 1).

Bioluminescent colonies grown on these plates were enumerated after incubating the plates for six days at $30^{\circ} \mathrm{C}$.

In order to mimic normal agricultural practice, one year after the release a part of the field plots was used to grow rye plants. On September $7^{\text {th }}, 1998$ soil samples were taken from all field plots and alfalfa plants were cut. During the next two days field plots number 29 to 49 (see Fig. 1) were dug up. On September $28^{\text {th }}, 1998$ the procedure was repeated, residual alfalfa plant material was removed and rye seeds were planted in the plots (see Fig. 1).

Sampling of bacteria from soil and data analyses

Soil samples were taken by auger insertions from the upper $25 \mathrm{~cm}$ of the soil layer. Five auger insertions randomly taken from each plot were mixed to represent the soil sample of the respective plot. The soil samples were air dried for one day at $25^{\circ} \mathrm{C}$ and sieved with a mesh size of $2 \mathrm{~mm}$ to remove roots and stones. A total of $10 \mathrm{~g}$ of soil from each sampling date was

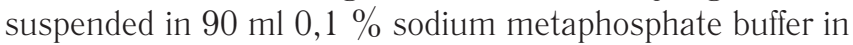
$250 \mathrm{ml}$ Erlenmeyer flasks and shaken with $10 \mathrm{~g}$ sterile gravel in a rotary shaker (200 rpm) for $30 \mathrm{~min}$ at room temperature. The suspension was diluted in sterile water and inoculated onto NPM-A agar. Bacterial colonies grown on NPM A medium were transferred onto nylon membranes (Hybond $\mathrm{N}^{\mathrm{TM}}$ Amersham, Braunschweig, Germany). Membranes were soaked in $200 \mu$ l luciferin solution ( $1 \mathrm{mM}$ luciferin in 100 $\mathrm{mM}$ sodium citrate solution). Colonies displaying bioluminescence were detected employing two different methods which, however, yielded identical results. The first method detected light-emission by bioluminescent colonies using Kodak-T-MAT DG films (Dresing et al., 1998). Employing this method, a detection limit of $10^{2} \mathrm{cfu} \mathrm{g}^{-1}$ soil was achieved. The second method relied on the identification of bioluminescent colonies grow on the agar plates by using a CCD (Charge Coupled Device) camera (Luminograph LB980, EG \& G Berthold, Bad Wildbad, Germany) which essentially yielded the same detection limit. The data obtained form the different treatments were analyzed by two way ANOVA tests to determine the significance of differences.

\section{Isolation of alfalfa nodulating rhizobia from soil samples}

Microcosms containing a mixture of $15 \mathrm{~g}$ soil from each sample and $70 \mathrm{~g}$ sterile washed Vermiculite (grain size 2-6 $\mathrm{mm}$ ) were seeded with five surface sterilized alfalfa seeds (Medicago sativa cv. DuPuits or cv. Europe ; Dresing et al., 1998). The plants were grown in a growth chamber for eight weeks $\left(16 \mathrm{~h}\right.$ light $/ 8 \mathrm{~h}$ dark; $20^{\circ} \mathrm{C} / 18{ }^{\circ} \mathrm{C} ; 70 \%$ relative humidity). The root nodules were removed with a sterile scalpel and stored at $-80^{\circ} \mathrm{C}$. Per soil sample $25-40$ nodules were analysed for the presence of bioluminescent rhizobia. The nodules were surface sterilized with a saturated $\mathrm{Ca}(\mathrm{OCl})_{2}$ solution and subsequently washed in sterile water. The bacteria were isolated by squashing the surface sterilized nodules in parallel onto TY agar medium and TY 
containing streptomycin ( $100 \mathrm{mg} \mathrm{l}$ ). S. meliloti cells isolated from nodules were resuspended in $50 \mu$ l water supplied with $10 \mu$ luciferin solution and tested for bioluminescence in a luminometer (Schwieger et al. 2000b).

\section{Molecular characterization of alfalfa nodulating rhizobia from soil samples}

PCR detection and discrimination of the $S$. meliloti isolates was performed as described by Dammann-Kalinowski et al. (1996) using two PCR primers, one specific for the luc gene, one specific for the DNA region downstream of the recA coding region. The Luc-positive and a representative number of Luc-negative cells were analyzed for their identity using the ERIC-PCR fingerprint method (DeBruijn 1992; Niemann et al, 1997b) with the modification that only primer ERIC2 (5-AAGTAAGTGACTGGGGTGAGCG-3) was used in the PCR reactions.

DNA template preparation and PCR reaction was performed as described previously (Niemann et al. 1997b). Briefly, total DNA was extracted from a single colony by boiling the cells in $50 \mathrm{ul}$ ff $1 \mathrm{f}$ lysis buer $(0.25 \% \mathrm{SDS} /$ $0.05 \mathrm{M} \mathrm{NaOH}$ ) at $95{ }^{\circ} \mathrm{C}$ f or $10 \mathrm{~min}$. One ul o a $1: 10 \mathrm{dilu}-$ tion of the resulting lysate was used per PCR reaction. $8 \mathrm{ul}$ of each PCR probe were separated in horizontal $2 \%$ agarose gels in Tris-acetate buffer for $150 \mathrm{~min}$ at $70 \mathrm{~V}$. The gels were stained with ethidium bromide and photographed on a UV transilluminator (312 nm) using a CCD camera (Cybertech, Germany). ERIC fingerprints of $S$. meliloti strains were processed using the Wincam software package (Cybertech, Germany). Similarity levels between two fingerprints were calculated with the Dice coefficient (Error level 20, Jackson et al. 1989). Band positions were determined employing the peakfinder function of the Wincam software package and subsequently controlled manually. All fingerprint pattern of individual isolates were controlled by two independent PCR amplifications. Dendrograms were calculated using the UPGMA method (Unweighted Pair Group Method Average Clustering, Felsenstein 1988).

\section{Southern hybridization}

Total DNA of rhizobial strains was isolated as described by Simon et al. (1991). Genomic DNA was digested with EcoRI and the restriction fragments were separated on Tris-Acetate ED TA gels containing $1 \%$ agarose. After ethidium bromide staining, gels were vacuum blotted onto a nylon membrane (Hybond-N, Amersham). For IS fingerprinting, a PCR amplicon derived from IS element ISRm2011-2 (Selbitschka et al. 1995b) was used to generate a specific probe.

For this purpose, a lysate established from a single colony of strain 2011 was used as the template (see previous paragraph). Primers ISss 1, 5'-GCGGTATGTATTTAAGCCCG-3' and ISss2, 5'-TAGAGCGGGATGCATTTAGG-3' were used in PCR amplifications employing the 10x labeling mix (Roche Diagnostics GmbH, Mannheim, Germany). Hybridization and detection of DNA-hybrids was carried out at $680 \mathrm{C}$ using the digoxigenin system (Boehringer) as instructed by the manufacturer.

\section{Determination of carbon, nitrogen and microbial biomass}

Soil parameters were analysed as described previously (Schwieger et al. 2000a). Total carbon was determined employing the dry combustion method using a CS-500 analyzer (Elktra GmbH, Neuss, Germany). Nitrate-N and ammonia- $\mathrm{N}$ were determined using colorimetric methods and analyzed with a segmented flow analyzer (Skalar analytic GmbH, Erkelenz, Germany). The microbial biomass was determined using the chloroform fumigation extraction technique and employing a liquiTOC analyzer (Foss Heraeus Analysesysteme, Hanau, Germany) for the analysis of the organic carbon, $\mathrm{A} \mathrm{k}_{\mathrm{EC}}$ factor of 0.378 was used for calculating the microbial biomass (Vance et al. 1987).

\section{Glyphosat treatment of field plots}

In order to terminate the release experiment and to reintroduce the field plots back to normal agricultural use, all field plots were treated with the herbicide RoundUp. For this purpose RoundUp was applied to all field plots inoculated with the luc tagged strains after soil tillage according to the manufacturers recommedations. In May 8, 2002, the procedure was repeated and, 5 weeks later, as well as in October of that year, the viable counts of the strains determined as described above.

\section{ACKNOWLEDGMENTS}

This work was supported by grants of the German Federal Ministry of Education and Research (BMBF). We thank Penny Hirsch for valuable discussion concerning the preparation of the peat-based inoculants. The contribution of the Bayerische Staatsministerium für Ernährung, Landwirtschaft und Forsten for making available the field release site in Strassmoos is gratefully acknowledged. We thank Rudolf Beck and the team of the Strassmoos experimental plant station for their excellent support during the field study.

\section{Literature}

1. Amarger N., 2002. Genetically modified bacteria in agriculture // Biochimie. Vol. 84. P. 1061-1072.

2. Bashan Y., 1998. Inoculants of plant-growth-promoting bacteria for use in agriculture // Biotechnol. Adv. Vol. 16. P. 729-770.

3. Beringer J. E., 1974. R-factor transfer in Rhizobium leguminosarum // J. Gen. Microbiol. Vol. 84. P. 188198.

4. Bromfield E. S. P., Wheatcroft R., Barran L. R., 1994. Medium for direct isolation of Rhizobium meliloti from soils // Soil Biol. Biochem. Vol. 26. P. 423-428.

5. Casse F., Boucher C., Julliot J. S., Denarié J., 1979. Identification and characterization of large plasmids in Rhizobium meliloti using agarose gel electrophoresis. J. Gen. Microbiol. Vol. 113. P. 229-242. 
6. Dammann-Kalinowski T., Niemann S., KellerM. et al.,1996. Characterization of two bioluminescent Rhizobium meliloti strains constructed for field releases // Appl. Microbiol. Biotechnol. Vol. 45. P. 509-512.

7. De Bruijn F., 1992. Use of repetitive (repetitive extragenic palindromic and enterobacterial repetitive intergeneric consensus) sequences and the polymerase chain reaction to fingerprint the genomes of Rhizobium meliloti isolates and other soil bacteria // Appl. Environ. Microbiol. Vol. 54. P. 2180-2187.

8. Dresing U., Hagen M., Selbitschka W. et al., 1998. Reduced survival of a RecA deficient Sinorhizobium meliloti strain in sterile and non-sterile soil during heat stress // FEMS Microbiol. Ecol. Vol. 27. P. 327-338.

9. Eardly B. D., Young J. P. W., Selander R. K., 1992. hylogenetic position of Rhizobium sp. strain Or 191, a symbiont of both Medicago sativa and Phaseolus vulgaris, based on partial sequences of the $16 \mathrm{~S}$ rRNA and nifH genes // Appl. Environ. Microbiol. Vol. 58. P. 1809-1815.

10. Felsenstein J. 1988. Phylogenies from molecular sequences: inference and reliability // Annu. Rev. Genet. Vol. 22. P. $521-565$.

11. Galibert F., Finan T. M., Long S. R. et al., 2001. The composite genome of the legume symbiont Sinorhizobium meliloti // Science. Vol. 293. P. 68-672.

12. Hagen M., Pühler A., Selbitschka W., 1997. The persistence of bioluminescent Rhizobium meliloti strains L1 (RecA-) and L33 (RecA+) in non-sterile microcosms depends on the soil type, on the co-cultivation of the host legume alfalfa and on the presence of an indigenous R. meliloti population // Plant Soil. Vol. 188. P. 257-266.

13. Herrera-Cervera J., Rodriguez-Alonso F. I., Olivares J., Sanjuan J., 1997. Evaluation of the recA-based containment system in Rhizobium meliloti GR4 // FEMS Microbiol. Ecol. Vol. 22. P. 49-59.

14. Hirsch P. R., 2004. Release of transgenic bacterial inoculants - rhizobia as a case study // Plant Soil Vol. 266. P. $1-10$

15. Jackson D. A., Somers K. M., Harvey H. H., 1989. Similarity coefficients: measures of co-occurrence and association or simply measures of occurrence? The American Naturalist Vol. 133. P. 437-453.

16. Kuhn S., Stiens M., Pühler A., Schlüter A., 2008 Prevalence of pSmeSM11a-like plasmids in indigenous Sinorhizobium meliloti strains isolated in the course ofa field release experiment with genetically modified S.meliloti strains. FEMS Microbiol. Ecol. Vol. 63. P. 118-131.

17. MiethlingR., Wieland G., Backhaus H., Tebbe C.C., 2000. Variation of microbial rhizosphere communities in response to crop species, soil origin, and inoculation with Sinorhizobium meliloti L33. Microb. Ecol. Vol. 40. P. 43-56.
18. Miethling R., Tebbe C. C., 2004. Resilience of a soil-established, genetically modified Sinorhizobium meliloti inoculant to soil management practices // Appl. Soil Ecol. Vol. 25. P. 161-167.

19. Niemann S., Pühler A., Selbitschka W., 1997a. Growth and nodulation competitiveness of Sinorhizobium meliloti L1 (RecA-) is less than that of its isogenic strain L33 (RecA+) but comparable to that of two S. meliloti wild type isolates // Appl. Microbiol. Biotechnol. Vol. 47:525-529.

20. Niemann S., Pühler A., Selbitschka W., 1997b. Evaluation of the resolving power of three different DNA fingerprinting methods to discriminate among isolates of a natural Rhizobium meliloti population // J. Appl. Microbiol. Vol. 82. P. 477-484.

21. Schwieger F, Willke B., Munch J. C., Tebbe C. C., 1997. Ecological pre-release risk assessment of two genetically engineered, bioluminescent Rhizobium meliloti strains in soil column model systems // Biol. Fertil. Soils Vol. 25. P. 340-348.

22. SchwiegerF., Dammann-Kalinowski T., Dresing $U$. et al., 2000a. Field lysimeter investigation with luciferase-gene (luc)-tagged Sinorhizobium meliloti strains to evaluate the ecological significance of soil inoculation and a recA-mutation // Soil Biol. Biochem. Vol. 32. P. 859-868.

23. Schwieger F., Tebbe C. C. 2000b. Effect of field inoculation with Sinorhizobium meliloti L33 on the composition of bacterial communities in rhizospheres of a target plant (Medicago sativa) and a non-target plant (Chenopodium album) - Linking of $16 \mathrm{~S}$ rRNA gene-based single-strand conformation polymorphism community profiles to the diversity of cultivated bacteria // Appl. Environ. Microb. Vol. 66. P. 3556-3565.

24. Selbitschka W., Arnold W., Priefer U.B. et al., 1991. Characterization of recA genes and recA mutants of Rhizobium meliloti and Rhizobium leguminosarum biovar viciae // Mol. Gen. Genet. Vol. 229. P. 9-19.

25. Selbitschka W., PühlerA., Simon R. 1992. The construction of recA-deficient Rhizobium meliloti and R. leguminosarum strains marked with gusA or luc cassettes for use in risk-assessment studies // Mol. Ecol. Vol. 1. P. 9-19.

26. Selbitschka W., Dresing U., Hagen M. et al., 1995a. A biological containment system for Rhizobium meliloti based on the use of recombination-deficient (recA ${ }^{-}$) strains // FEMS Microbiol. Ecol. Vol. 16. P. 223-232.

27. Selbitschka W., Arnold W., Jording D. et al., 1995b. The insertion sequence element ISRm2011-2 belongs to the IS630-Tc1 family of transposable elements and is abundant in Rhizobium meliloti // Gene Vol. 163. P. 59-64.

28. SelbitschkaW., KellerW., Miethling-GraffR. et al., 2006. Long-term field release of bioluminescent Sinorhizobium meliloti strains to assess the influence of a 
recA mutation on the strains' survival //Microbial Ecol. Vol. 52. P. 583-595.

29. Simon R., Hötte B., Klauke B., Kosier B., 1991. Isolation and characterization of insertion sequence elements from Gram-negative bacteria by using new broad-host-range, positive selection vectors // J. Bacteriol. Vol. 173. P. 1502-1508.

30. Somasegaran P., Hoben H. J., 1994. Handbook for Rhizobia. - Springer Press, New York.

31. Stiens M., SchneikerS., KellerM. et al., 2006. Sequence analysis of the 144-kilobase accessory plasmid pSmeSM11a, isolated from a dominant Sinorhizobium meliloti strain identified during a long-term field release experiment. Appl. Environ. Microbiol. Vol. 72. P. 3662-3672.

32. Stiens M., Schneiker S., Pühler A., SchlüterA., 2007. Sequence analysis of the $181-\mathrm{kb}$ accessory plasmid pSmeSM11b, isolated from a dominant Sinorhizobium meliloti strain identified during a long-term field release experimen // FEMS Microbiol. Lett. Vol. 271. P. 297-309.

33. Thies J. E., Singleton P. W., Bohlool B. B., 1991. Influence of the size of indigenous rhizobial populations on establishment and symbiotic performance of introduced rhizobia on field-grown legumes // Appl. Environ. Microbiol. Vol. 57. P. 19-28.

34. Vance E. D., Brookes P. C., Jenkinson D. S., 1987. An extraction method for measuring soil microbial biomass // C. Soil Biol. Biochem. Vol. 19. P. 703-707.

35. van Veen J.A., van Overbeek L.S., van ElsasJ.D., 1997. Fate and activity of microorganisms introduced into soil// Microbiol. Mol. Biol. Rev. Vol. 61. P. $121-135$.
Динамика экологических взаимодействий штамма 2001 Sinorhizobium meliloti, маркированного геном светлячка, в почве, содержащей многочисленные популяции ризобий, образующих клубеньки

Зельбичка В., Келлер М., Дресинг У.,

Даммн-Калиновски Т., Кран И.,

Шнейкер С., Шафер Д., Лотс В.,

Миетлинг-Граф Р., Теббе К., Пюлер А.

8 РЕЗЮМЕ: Рассматриваются молекулярные механизмы симбиотических взаимодействий между сельскохозяйственно-значимыми растениями и микроорганизмами, играющих важную роль в питании и защите растений. Такие симбиозы основаны на сигнальных взаимодействиях, приводящих к развитию новых тканевых/клеточных структур, а также к расширению метаболических возможностей у партнеров, что в значительной степени улучшает адаптивный потенциал растений вследствие устойчивости к биотическому или абиотическому стрессу. Данные, касающиеся молекулярных, генетических или экологических особенностей растительно-микробных взаимодействий, обеспечивают методологию создания устойчивых сельскохозяйственных культур, основанную на замещении химикатов (минеральных удобрений и пестицидов) микробиологическими препаратами. Усовершенствование растительно-микробных симбиозов должно включать согласованные изменения обоих партнеров, обеспечивающие создание комплементарных сочетаний их генотипов.

К КЛЮЧЕВЫЕ СЛОВА: люцерна, Sinorhizobium meliloti, маркирование геном luc, конкуренция за клубенькообразование, местные популяции, выпуск в среду генетически модифицированных бактерий. 